\title{
Variation in the size of the repeat region of the fibrinogen receptor (clumping factor) of Staphylococcus aureus strains
}

\author{
Damien McDevitt $†$ and Timothy J. Foster
}

Department of Microbiology, Moyne Institute, Trinity College, Dublin 2, Ireland
Author for correspondence: Timothy J. Foster. Tel: +3531 7022014. Fax: +35316799294.

\begin{abstract}
The ability of Staphylococcus aureus to bind to fibrinogen and fibrin is believed to be an important factor in the initiation of foreign body and wound infections. Recently, the gene encoding the fibrinogen receptor (clumping factor, ClfA) of S. aureus strain Newman was cloned and sequenced. The ClfA protein possesses a highly unusual 308 residue dipeptide repeat region composed predominantly of Asp and Ser. Polymerase chain reaction analysis of seven different strains showed that the size of the clfA repeat coding region varies from $580 \mathrm{bp}$ to $1320 \mathrm{bp}$. In contrast, the clfA region A is the same size in each strain. The size of the clfA repeat region did not correlate with the ability of these strains to form clumps in a solution of fibrinogen. Indeed, the strain with the smallest repeat size of $\mathbf{5 8 0}$ bp clumped almost as well as strain Newman. Each strain of $S$. aureus examined contained several high molecular mass proteins that reacted with anti-ClfA region A antibody. In some cases the molecular mass of the major protein varied in accordance with the length of the coding sequence for the repeat region $R$.
\end{abstract}

Keywords: Staphylococcus aureus, fibrinogen receptor, clumping factor

\section{INTRODUCTION}

Stapbylococcus aureus is an important pathogen that is responsible for a variety of infections of both man and animals. It is a major cause of hospital acquired infections (Shanson, 1990) and can cause wound infections and infections associated with indwelling medical devices including catheters and surgical prostheses (Maki, 1982; Kristinsson, 1980). These infections can lead to life threatening sequels such as septicaemia and endocarditis. Colonization has been identified as a key step in the pathogenic process. When medical devices are introduced into the body they become coated with host plasma proteins including fibrinogen and fibronectin (Cottonaro et al., 1981; Cheung \& Fischetti, 1989; Vaudaux et al., 1989). In particular, intact fibrinogen is the predominant protein deposited on biomaterials during short-term contact with blood (Vaudaux et al., 1991). Prolonged contact results in degradation of fibrinogen and loss of its binding site for $S$. aureus and the emergence of fibronectin as the pre-eminent determinant of adherence (Vaudaux et al., 1993). The ability of $S$. aureus to bind to these

†Present address: Institute of Biosciences and Technology, Center for Extracellular Matrix Biology, Texas A \& M University, Houston, Texas 77030 , USA. deposited proteins is believed to be an important factor in the pathogenesis of foreign body infections.

The structure of the receptor for fibrinogen on the surface of $S$. aureus strain Newman (sometimes called the clumping factor, ClfA) has been deduced from the DNA sequence (McDevitt et al., 1994). The deduced amino acid sequence of the ClfA protein revealed features characteristic of proteins located at the surface of Gram-positive bacteria, namely the sequence LPDTG which corresponds to the motif LPXTG, followed by a hydrophobic transmembrane domain and then several positively charged residues (Fig. 1). ClfA lacks an extensive proline-

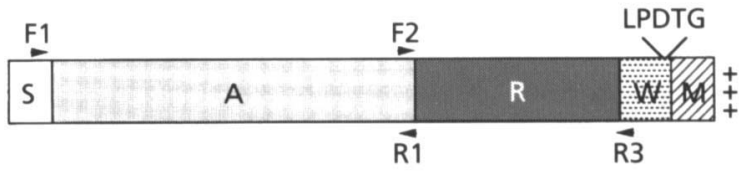

Fig. 1. Schematic diagram showing the domain organization of the ClfA protein of $S$. aureus strain Newman. $S$, signal peptide; $A$, non-repeat region; $R$, repeat region; $W$, wall region; $M$, membrane spanning region; + , positively charged residues. $F 1$ and F2, forward primers; R1 and R3; reverse primers. The location of LPDTG is indicated. 
and glycine-rich region characteristic of protein $A$ and the fibronectin-binding proteins (Guss et al., 1984; Signas et al., 1989; Jonsson et al., 1992). A 39 residue sequence that has all the features of a secretory signal sequence is located at the $\mathrm{N}$-terminus of ClfA. This is followed by a 520 residue non-repeated region A (Fig. 1) which contains the fibrinogen-binding domain (D. McDevitt \& T. J. Foster, unpublished data). A novel 308 residue repeat region (region $R$ ) is found between region $A$ and the $C$ terminal wall- and membrane-associated regions (Fig. 1). It is composed of 154 dipeptide repeats predominantly of Asp and Ser and ends 28 residues upstream of LPDTG.

The dipeptides are coded for predominantly by an $18 \mathrm{bp}$ DNA repeat, with a consensus of GAY TCN GAY TCN GAY AGY where $\mathrm{N}$ is any base and $\mathrm{Y}$ is $\mathrm{T}$ or $\mathrm{C}$ (McDevitt $e t$ al., 1994). There are 52 DNA repeat units, two of which (numbers 45 and 51) consist of $12 \mathrm{bp}$. Of the 5018 bp repeats, 31 encode Ser and Asp exclusively. The sequence of the $\operatorname{clf} A$ repeat region diverges at either end, which is consistent with the hypothesis that it evolved by intragenic recombination. This type of divergence is also found in the repeats of protein A (Uhlen et al., 1984) and coagulase (Phonimdaeng et al., 1990). The function of the ClfA repeat region is not known. It may act as a 'stalk' to project the biologically active fibrinogen-binding region from the cell surface or it may serve as a mechanism for attaching the protein to the cell wall similar to the proline and glycine repeats of protein $A$.

This study investigated the sizes of the $\operatorname{clf} A$ repeat regions in different clumping factor producing $S$. aureus strains using PCR. The repeat region was found to vary from $580 \mathrm{bp}$ to $1320 \mathrm{bp}$. The repeat length did not correlate with the fibrinogen clumping titre. The variation in size of the clumping factor protein was investigated by Western immunoblotting.

\section{METHODS}

Bacterial strains. The strains are listed in Table 1.

PCR analysis. PCR was used to amplify both the region $A$ and the repeat region $\mathrm{R}$ from the chromosomal clf $A$ gene of the $S$. aureus strains in Table 1 . To amplify the region $\mathrm{A}$ of $\operatorname{clf} A$ the forward primer $5^{\prime}$ TATGCCATGGTAGG'TACGTTAATCGG 3' (F1) (starting at position 67) and reverse primer 5' TACAAGCTTGCTCATCAGGTTGTTCAGG 3' (R1) (ending at position 1651) were used. To amplify the $\operatorname{lf} A$ repeat region $\mathrm{R}$ the forward primer $5^{\prime}$ ATTACCATGGAACAACCTGATGAGCC 3' (F2) (starting at position 1636) and reverse primer 5' GTCAAGCT'TAGGTGAATTAGGCGG 3' (R3) (ending at position 2633) were used. The bp coordinates refer to the ATG codon of the clf $A$ gene of strain Newman (accession number Z18852 SAU CF). It should be noted that these primers contain $5^{\prime}$ extensions (underlined) which do not hybridize to clf $A$ sequences. Thus the PCR products will be $18 \mathrm{bp}$ and $16 \mathrm{bp}$ larger, respectively, than predicted from the $5^{\prime}$ and $3^{\prime}$ coordinates. PCR was performed with a Cetus/Perkin Elmer DNA Thermocycler. Genomic DNA was isolated from $S$. aureus strains by the method of Bollet $e$ t al. (1991). Reaction mixtures $(100 \mu \mathrm{l})$ contained $100 \mathrm{ng}$ target DNA, $200 \mathrm{pM}$ of forward and reverse primers, $1.5 \mathrm{mM} \mathrm{MgCl}, 2 \mu \mathrm{M}$ of each dNTP, $10 \mathrm{mM}$ Tris $/ \mathrm{HCl} \mathrm{pH} \mathrm{9,50} \mathrm{mM} \mathrm{KCl,} \mathrm{0.1 \%} \mathrm{Triton} \mathrm{X-100} \mathrm{and} 2.5 \mathrm{U}$ Taq
DNA polymerase (Promega). The reaction mixtures were overlaid with $100 \mu \mathrm{l}$ mineral oil and amplified for 30 cycles consisting of a $1 \mathrm{~min}$ denaturation period at $94^{\circ} \mathrm{C}$, a $1 \mathrm{~min}$ anneal period at $45^{\circ} \mathrm{C}$ and a $1 \mathrm{~min}$ extension period at $72^{\circ} \mathrm{C}$. After amplification, $10 \mu \mathrm{l}$ PCR product was analysed by agarose gel electrophoresis $(1 \%, \mathrm{w} / \mathrm{v}$, agarose $)$. Standards were the $100 \mathrm{bp}$ ladder purchased from Gibco-BRL.

Manipulation of DNA. DNA-modifying enzymes were purchased from Boehringer or from Promega and were used according to the manufacturers' instructions. DNA manipulations were performed using standard procedures (Sambrook et al., 1989; Ausubel et al., 1987). DNA hybridization was performed by the method of Southern (1975). Probe DNA was labelled by random priming using $\left[\alpha^{32} \mathrm{P}\right] \mathrm{dATP}$ (Amersham) and the Prime-A-Gene Kit (Promega). PCR amplification of plasmid pCF14 (carrying the cloned clf $A$ gene) using F1 and R1 primers resulted in a 1600 bp product which was gel-purified and used as the $\operatorname{clf} A$ region $A$ probe. PCR amplification of plasmid pCF14 using F2 and R3 primers resulted in a $1020 \mathrm{bp}$ product which was gel-purified and used as the $\operatorname{clf} A$ repeat region $\mathrm{R}$ probe.

Measurement of clumping titre. The clumping titres of $S$. aureus strains were measured as previously described (McDevitt et al., 1992). Briefly, serial twofold dilutions of a $2 \%(\mathrm{w} / \mathrm{v})$ solution of fibrinogen (Sigma) was made in phosphate-buffered saline (PBS; $0 \cdot 145 \mathrm{M} \mathrm{NaCl}, 0 \cdot 15 \mathrm{M}$ sodium phosphate). Bacteria were grown for $15 \mathrm{~h}$ in $20 \mathrm{ml}$ trypticase soy broth in a $250 \mathrm{ml}$ flask shaken at 200 r.p.m. A suspension of $2 \times 10^{9}$ washed cells $(20 \mu \mathrm{l})$ was added to $50 \mu \mathrm{l}$ of the fibrinogen dilutions in microtitre trays. The reciprocal of the highest dilution of fibrinogen showing clumping after $3 \mathrm{~min}$ was recorded as the titre.

SDSPAGE and Western immunoblotting. Proteins were extracted from $S$. aureus cells as follows. Bacteria were grown for $15 \mathrm{~h}$ in trypticase soy broth $(20 \mathrm{ml})$ in a $250 \mathrm{ml}$ flask shaken at 200 r.p.m. Cells were harvested by centrifugation at $12000 \mathrm{~g}$ and resuspended in $2 \mathrm{ml}$ PBS containing $40 \mu \mathrm{g}$ DNaseI ml ${ }^{-1}$, $40 \mu \mathrm{g}$ RNase I ml $\mathrm{m}^{-1}, 2 \mathrm{mM}$ of the protease inhibitors PMSF and benzamidine, and recombinant lysostaphin (Applied Microbiology) at $50 \mu \mathrm{g} \mathrm{ml}^{-1}$. Cells were incubated at $37^{\circ} \mathrm{C}$ for $2 \mathrm{~h}$ followed by centrifugation at $30000 \mathrm{~g}$ for $30 \mathrm{~min}$. The supernatants were stored in aliquots at $-20^{\circ} \mathrm{C}$.

Escherichia coli strains harbouring plasmids were grown for $15 \mathrm{~h}$ with shaking at 200 r.p.m. in $50 \mathrm{ml} \mathrm{L}$ broth with ampicillin at $100 \mu \mathrm{g} \mathrm{ml}^{-1}$. Cells were harvested by centrifugation at $12000 \mathrm{~g}$

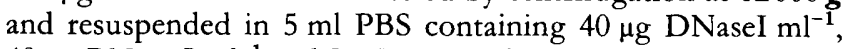
$40 \mu \mathrm{g}$ RNase $\mathrm{I} \mathrm{ml}^{-1}$ and $2 \mathrm{mM}$ each of PMSF, benzamidine and EDTA. Cells were lysed by passage through a French press followed by centrifugation at $30000 \mathrm{~g}$ for $30 \mathrm{~min}$. The supernatants were stored in aliquots at $-20^{\circ} \mathrm{C}$. The protein concentration was determined by the Bio-Rad protein assay method using human fibrinogen as a standard.

Proteins were separated by SDS-PAGE which was performed by standard procedures (Laemmli, 1970) with $7.5 \%(\mathrm{w} / \mathrm{v}$ ) acrylamide gels. Proteins were transferred from the gel to nitrocellulose membranes $(0 \cdot 45 \mu \mathrm{m}$, Schleicher \& Schuell) using a semidry blotter (Bio-Rad) and $48 \mathrm{mM}$ Tris $/ \mathrm{HCl}, 39 \mathrm{mM}$ glycine $(\mathrm{pH} \mathrm{9 \cdot 2)}$ and $20 \%(\mathrm{v} / \mathrm{v})$ methanol. Filters were blocked with a $10 \%(\mathrm{w} / \mathrm{v})$ solution of skim milk in PBS. ClfA proteins were detected with rabbit anti-ClfA antibodies prepared by immunization with purified region A of clumping factor that had been amplified by recombinant techniques (D. McDevitt \& T. J. Foster, unpublished). The antibody was adsorbed with an E. coli TB1 lysate and used at a dilution of 1 in 1000 followed by 
Table 1. Strains

\begin{tabular}{|c|c|c|}
\hline Strain & Description & Source/reference \\
\hline \multicolumn{3}{|c|}{$\begin{array}{l}\text { Staphylococcus } \\
\text { aureus }\end{array}$} \\
\hline Newman & $\begin{array}{l}\text { Archetypal clumping factor producer } \\
\text { NCTC } 8178\end{array}$ & Duthie \& Lorenz (1952) \\
\hline DU5876 & $\begin{array}{l}\text { Clumping factor defective Tn917 } \\
\text { mutant of strain Newman }\end{array}$ & McDevitt et al. (1994) \\
\hline C304/11 & Bovine mastitis isolate & Jones \& Wiencke (1986) \\
\hline Cowan & NCTC 8530 & \\
\hline V37 & Septicaemia isolate from Dublin & $\begin{array}{l}\text { Humphreys et al. (1989) } \\
\text { O'Reilly et al. (1990) }\end{array}$ \\
\hline V41 & Septicaemia isolate from Dublin & $\begin{array}{l}\text { Humphreys et al. (1989) } \\
\text { O'Reilly et al. (1990) }\end{array}$ \\
\hline V48 & Septicaemia isolate from Dublin & $\begin{array}{l}\text { Humphreys et al. (1989) } \\
\text { O'Reilly et al. (1990) }\end{array}$ \\
\hline V82 & Septicaemia isolate from Dublin & $\begin{array}{l}\text { Humphreys et al. (1989) } \\
\text { O'Reilly et al. (1990) }\end{array}$ \\
\hline \multicolumn{3}{|c|}{ Escherichia coli } \\
\hline TB1 & Host for chimeric plasmids & $\begin{array}{l}\text { Yanisch-Perron et al. } \\
\text { (1985) }\end{array}$ \\
\hline $\mathrm{TB} 1(\mathrm{pCF} 3)$ & $\begin{array}{c}\mathrm{pCF} 3 \text { carries the } \text { clf } A \text { gene on a } 7 \mathrm{~kb} \\
\text { HindIII fragment cloned in pUC18 }\end{array}$ & McDevitt et al. (1994) \\
\hline TB1(pCF14) & $\begin{array}{l}\text { pCF14 carries the } \operatorname{clf} A \text { gene on a } \\
3.5 \mathrm{~kb} \text { HindIII-KpnI fragment } \\
\text { cloned in pUC18 }\end{array}$ & McDevitt et al. (1994) \\
\hline
\end{tabular}

incubation with protein A conjugated with peroxidase (1/500, Sigma).

\section{RESULTS}

\section{Variation in the size of the clfA repeat region}

Chromosomal DNA was isolated from seven different $S$. aureus strains from a variety of human and bovine sources (Table 1) and analysed by PCR. For amplification of the region $\mathrm{A}$ of $c$ lf $A$, primers $\mathrm{F} 1$ and $\mathrm{R} 1$ (designed to anneal to sequences flanking the region $\mathrm{A}$ of strain Newman) were used while region $\mathrm{R}$ was amplified with primers $\mathrm{F} 2$ and R3 (designed to anneal to sequences flanking the $\operatorname{clf} A$ repeat region $R$ of strain Newman) (Fig. 1).

Amplification of the repeat region $\mathbf{R}$ of strain Newman generated a product of $1020 \mathrm{bp}$ (Fig. 2a, lane 1). This correlated well with the fragment size predicted from the DNA sequence (1013 bp, including primers). Fig. 2(a) shows the variability in the size of the $\operatorname{clf} A$ repeat regions of six other strains compared to strain Newman. The sizes varied from $580 \mathrm{bp}$ for strain V37 (lane 2) to $1320 \mathrm{bp}$ for strain V48 (lane 7). Most strains had a significantly larger clf $A$ repeat region compared to that of strain Newman. When analysis was expanded to a panel of 37 strains from various sources, $92 \%$ of strains $(34 / 37)$ had a repeat region equal to or greater than that of strain Newman (data not shown).

Southern hybridization analysis using a specific probe for the lf $A$ repeat region of strain Newman was performed to ensure that the PCR products were amplified from the clf $A$ repeat region. The major PCR product in each sample hybridized with the probe (Fig. 2b). A second fainter product was observed for some strains (Fig. 2a, lanes 4, 6 and 7). In each case these failed to hybridize to the probe showing that they represent non-specific products.

Amplification of region A of strain Newman generated a product of $1600 \mathrm{bp}$ (Fig. 3a, lane 1). This correlated well with the fragment size predicted from the DNA sequence (1602 bp, including primers). In contrast to the clf $A$ repeat region, the size of the region $A$ was the same in all the strains tested (Fig. 3a). Southern hybridization analysis, using a specific probe for region A of strain Newman, was performed on the PCR products. Each of the PCR products hybridized with the region A specific probe (Fig. 3b).

\section{Clumping factor activity of $\boldsymbol{S}$. aureus strains}

Strain Newman is the archetypal clumping factor producing strain of $S$. aureus (Duthie \& Lorenz, 1952; Hawiger et al., 1982). It consistently gave a high titre (2048) in the quantitative clumping assay with soluble fibrinogen (Table 2) whereas the clumping factor deficient mutant of strain Newman (DU5876) failed to clump even at the highest concentration. No correlation was found between the clumping titre and the size of the $\operatorname{clf} A$ repeat region. Strain V37 which had the smallest $\operatorname{clf} A$ repeat 
(a)

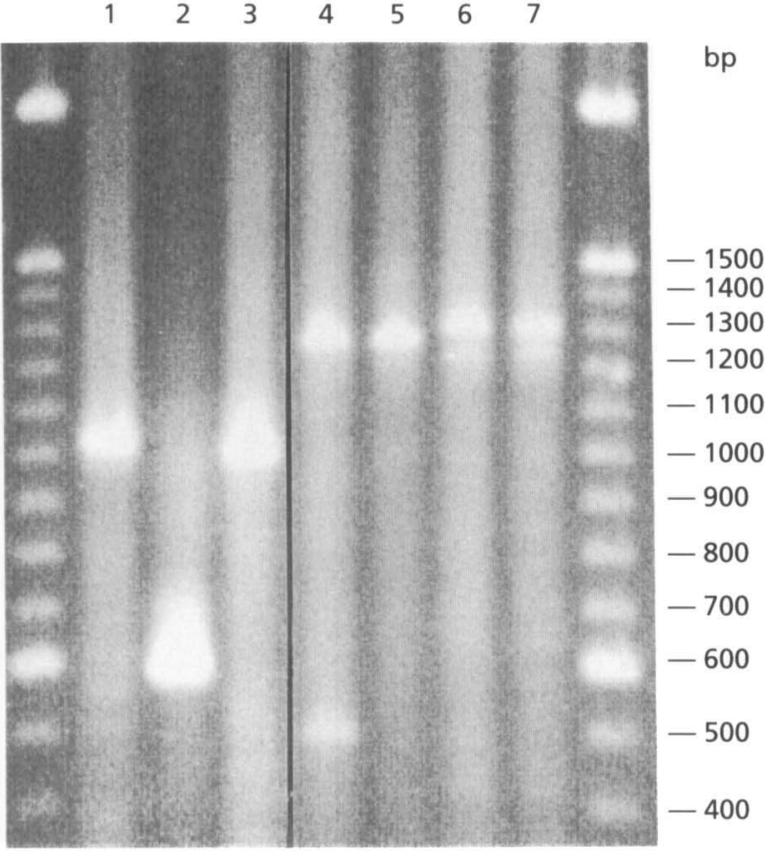

(b)

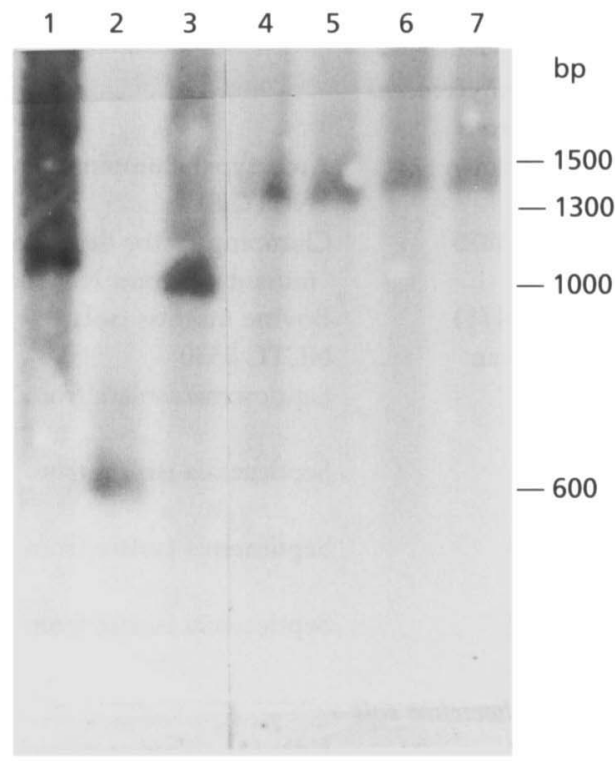

Fig. 2. (a) $P C R$ analysis of the clfA repeat region. Chromosomal DNA from the various strains was amplified by $P C R$ using the F2 and R3 primers. (b) Southern hybridization analysis of the clfA repeat region PCR products. The PCR products isolated using primers F2 and R3 were probed with the clfA repeat region probe. Lanes: 1, strain Newman; 2, strain V37; 3, strain C304/11; 4, strain V82; 5, strain Cowan; 6, strain V41; 7, strain V48. The 100 bp ladder was used as size standards.

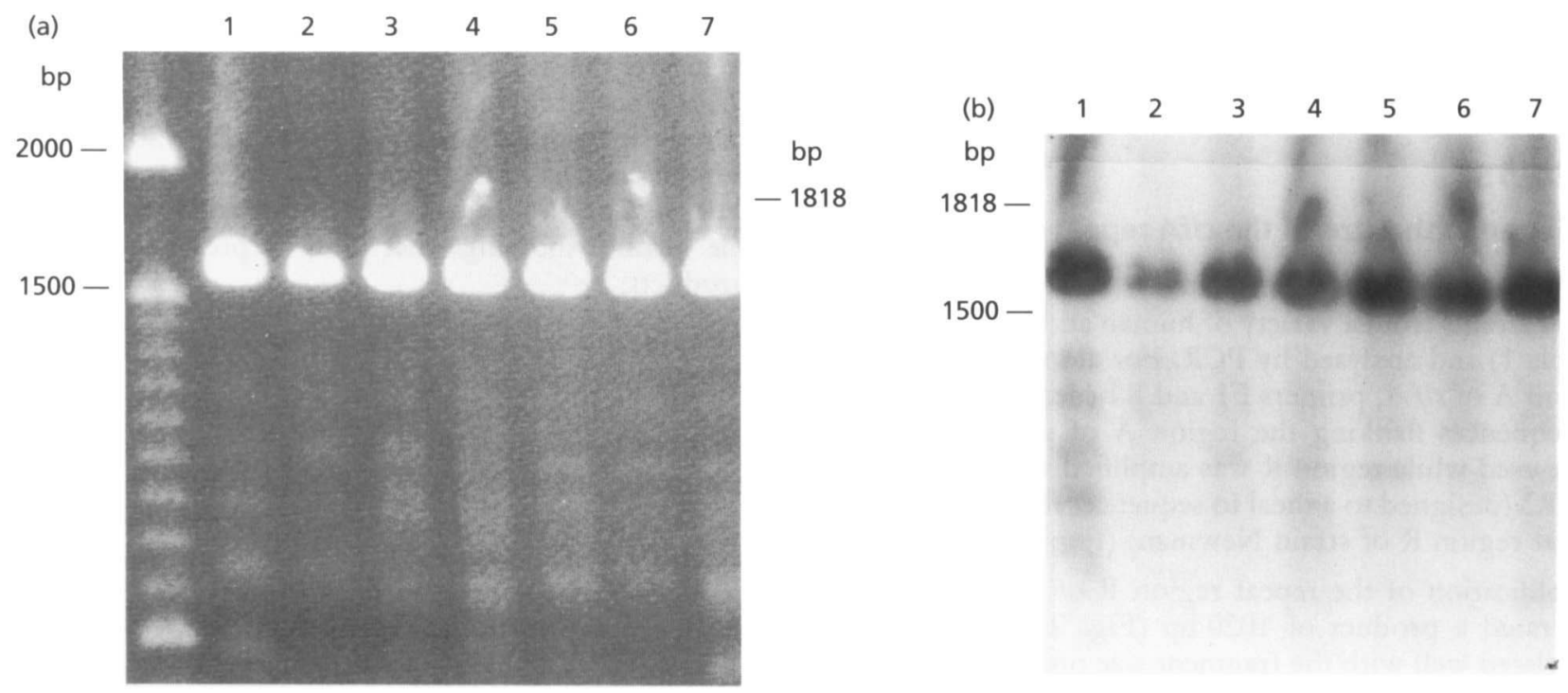

Fig. 3. (a) PCR analysis of the clfA region A. Chromosomal DNA from the various strains was amplified by PCR using the F1 and R1 primers. (b) Southern hybridization analysis of the clfA region A PCR products. The PCR products isolated using primers F1 and R1 were probed with the clfA region A probe. Lanes: 1, strain Newman; 2, strain V37; 3, strain C304/11; 4, strain V82; 5 , strain Cowan; 6 , strain V41; 7, strain V48.

clumped almost as strongly as strain Newman while strains V41 and V48, which had the largest clf $A$ repeat regions, had clumping titres of 256 (Table 2). None of the strains tested had a higher clumping factor titre than strain Newman.

\section{Analysis of clumping factor proteins}

Proteins released from the cell by lysostaphin digestion of the clumping factor producing $S$. aureus strains and a lysate of $E$. coli expressing the cloned olf $A$ gene were 
Table 2. Clumping titres and sizes of the clfA repeat regions of the various strains

\begin{tabular}{|lcc|}
\hline Strain & $\begin{array}{c}\text { Clumping } \\
\text { titre* }\end{array}$ & $\begin{array}{c}\text { PCR } \\
\text { fragment } \\
\text { size } \\
\text { (bp) } \dagger\end{array}$ \\
\hline Newman & 2048 & 1020 \\
DU5876 & $<2$ & ND \\
V37 & 1024 & 580 \\
C304/11 & 2048 & 990 \\
V82 & 1024 & 1280 \\
Cowan & 2048 & 1290 \\
V41 & 256 & 1320 \\
V48 & 256 & 1320 \\
\hline
\end{tabular}

ND, Not determined.

* Average of three experiments.

† Approximate size.

analysed by Western immunoblotting with anti-ClfA antibodies. The lysate of E. coli TB1(pCF3) (carrying the cloned strain Newman clf $A$ gene) contained several immunoreactive proteins (Fig. 4, lane 2) which were absent in a lysate of E. coli TB1 without the plasmid (Fig. 4, lane 1). The largest of these was $190 \mathrm{kDa}$. S. aureus strain Newman expressed a $190 \mathrm{kDa}$ immunoreactive protein (Fig. 4, lane 3). A smaller immunoreactive protein of $130 \mathrm{kDa}$ was also detected. Despite the presence of protease inhibitors and testing samples from cells harvested from mid-exponential to late-stationary phase, two proteins were always present. Both proteins were absent in the clumping factor mutant strain DU5876 (Fig. 4 , lane 4) indicating that they are products of the $\operatorname{clf} A$ gene.

Two or more immunoreactive proteins were found in each of the other strains tested. In some strains a tentative correlation could be made between the largest immunoreactive protein and the size of the $\operatorname{clf} A$ repeat region detected by PCR but there were several exceptions. The largest immunoreactive protein of V37 (580 bp repeat region) was $170 \mathrm{kDa}$ (Fig. 4, lane 5) while strains $\mathrm{V} 41$ and V82 which had the largest repeats (1320 bp) expressed immunoreactive proteins of $>200 \mathrm{kDa}$ (Fig. 4, lanes 10 and 11). In strain Cowan (lane 8) an even higher molecular mass band is evident. This could represent an undenatured aggregate of ClfA or cross-reaction with another protein. The faint protein of $56 \mathrm{kDa}$ in some of the samples is most probably protein $A$. This protein was absent in a sample of proteins released from a protein-A-deficient mutant of

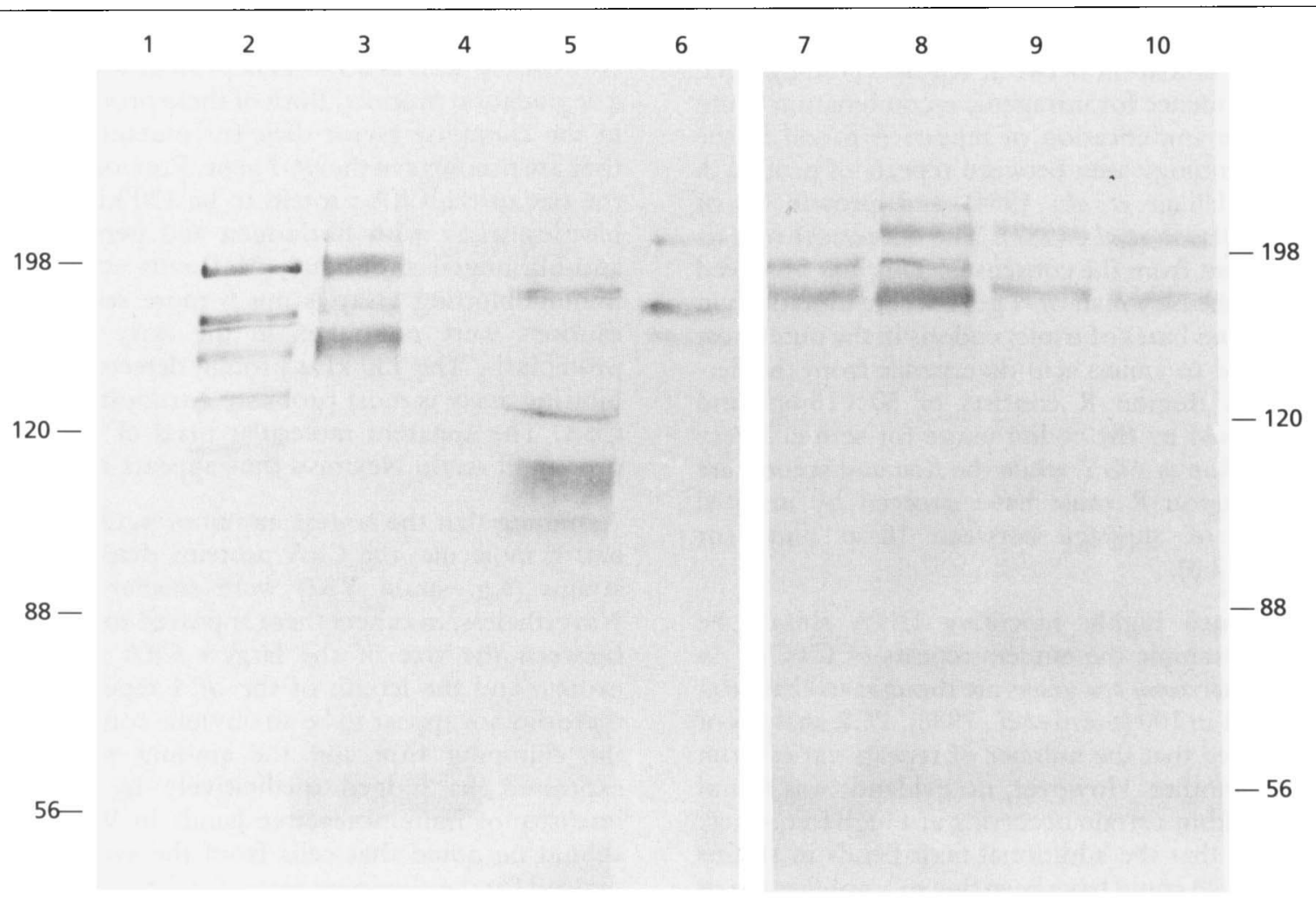

Fig. 4. Western immunoblotting analysis of ClfA proteins. Samples from E. coli strains TB1 (lane 1) and TB1(pCF3) (lane 2) and from S. aureus strains Newman (lane 3), DU5876 (lane 4), V37 (lane 5), strain C304/11 (lane 6), strain V82 (lane 7), strain Cowan (lane 8), strain V41 (lane 9) and strain V48 (lane 10) were transferred to a nitrocellulose membrane. The membrane was incubated with anti-ClfA antibodies followed by protein A peroxidase. One hundred micrograms of protein extract was loaded for E. coli TB1, E. coli TB1(pCF3) and for strains Newman and DU5876 while $500 \mu g$ protein was loaded for strains V37, C304/11, V82, Cowan, V41 and V48. 
strain Newman (data not shown). Using proteinA-peroxidase to detect $\operatorname{Ig} G$ does not entirely eliminate detection of $\operatorname{IgG}$ bound by the non-immune mechanism to protein $\mathrm{A}$.

\section{DISCUSSION}

The primary objective of this study was to determine if the $\operatorname{clf} A$ repeat region varied in size among $S$. aureus strains from different sources. This was achieved by PCR using primers designed to anneal to sequences directly flanking the strain Newman $\operatorname{clf} A$ repeat region. A PCR product was obtained with each of the seven strains tested suggesting that the primer binding regions are conserved. In addition, the fact that the $1020 \mathrm{bp}$ PCR product from strain Newman was very close to the size (1013 bp) predicted from the DNA sequence suggests that the $\operatorname{clf} A$ repeat sizes from other strains are accurate estimates. Southern hybridization analysis confirmed that the PCR products are derived from the $\operatorname{lf} A$ repeat. A significant size variation in the $\operatorname{clf} A$ repeat regions was observed. The smallest $\operatorname{clf} A$ repeat region was $580 \mathrm{bp}$ while the largest was $1320 \mathrm{bp}$. It is known that tandemly repeated DNA sequences can act as hotspots for recombination or slipped strand mispairing. This can result in the formation of deletions or duplications (Hollingshead et al., 1987; Fischetti et al., 1986; Stern et al., 1986). Size variation has been reported in type M6 proteins of Group A streptococci and this was shown to be generated by intragenic recombination between repeats (Hollingshead et al., 1987). Evidence for intragenic recombination being involved in the amplification of repeats is found in the gradient of homology seen between repeats of protein $A$ of $S$. aureus (Uhlen et al., 1984) and protein G of streptococci (Olsson et al., 1987). The outermost repeats are most different from the consensus. This was observed in region $\mathrm{R}$ of the Newman clf $A$ gene where mutations in the first or second bases of triplet codons in the outermost repeats have led to amino acid divergence from the SerAsp dipeptide. Region $\mathrm{R}$ consists of $50 \times 18 \mathrm{bp}$ (and $2 \times 12 \mathrm{bp}$ ) defined by the codon usage for serine. Every third serine codon is AGY while the first and second are TCN. Thus region $\mathrm{R}$ must have evolved by unequal crossing over or slippage between $18 \mathrm{bp}$ units (or multiples of $18 \mathrm{bp}$ ).

In principle such highly repetitive DNA should be unstable. For example the tandem repeats of CTCTT in the Neisseria gonorrboeae opa genes are thought to change at a frequency of 1 in 100 (Stern et al., 1986). PCR analysis of region $\mathrm{R}$ showed that the number of repeats varies from one strain to another. However, no evidence was found for variation within a strain occurring at a high frequency. We consideted that the additional faint bands in strains V82, V41 and V48 could have been due to amplification of variant repeat regions with the population. However these bands did not react with the region $\mathrm{R}$ probe and are thus probably due to non-specific amplification events. Also, a line of strain Newman kept in this laboratory for 20 years had the same repeat length as the derivative obtained from the NCTC. The DNA sequence of the region $\mathrm{R} 18$ bp repeats in strain Newman vary considerably from one to another. Neighbouring $18 \mathrm{bp}$ repeats differ by as many as six positions while only two pairs of adjacent $18 \mathrm{bp}$ repeats are identical. Analysis of the 31 Ser-Asp encoding repeats shows that they are saturated for mutations in the third position with the mean number of differences being three (D. Shields, D. McDevitt \& T. J. Foster, unpublished data). The high level of mismatching may reduce the potential for unequal crossing over and replication slippage and could have evolved to preserve the integrity of region $R$.

Many of the strains tested had a larger repeat region than strain Newman while strain V37 had a smaller repeat of $580 \mathrm{bp}$. The latter was able to clump almost as well as strain Newman. In addition, strains V41 and V48 which had repeats of $1320 \mathrm{~kb}$ had a low titre of 256 . Thus, there is no correlation between the length of the repeat and the ability of the strains to clump in soluble fibrinogen.

The largest immunoreactive protein expressed by $E$. coli TB1(pCF3) (carrying the cloned clf $A$ gene) was $190 \mathrm{kDa}$. The smaller immunoreactive proteins are probably degradation products which occurred despite the presence of protease inhibitors in the sample. In samples that were prepared from late-stationary phase cultures or which were repeatedly frozen and thawed, the $190 \mathrm{kDa}$ band was missing. Alternatively, the smaller proteins may be due to premature translational termination. An immunoreactive protein of $190 \mathrm{kDa}$ was also expressed by $S$. aureus strain Newman as well as a $130 \mathrm{kDa}$ protein which may also be a degradation product. Both of these proteins were absent in the clumping factor deficient mutant indicating that they are products of the $\operatorname{clf} A$ gene. Previously we reported the size of the ClfA protein to be $130 \mathrm{kDa}$ in an affinity blotting assay with fibrinogen and peroxidase labelled anti-fibrinogen antibodies (McDevitt et al., 1994). The immunoblotting assay is much more sensitive and precautions were not taken in the early work to avoid proteolysis. The $130 \mathrm{kDa}$ protein detected in the affinity blotting assay is most probably a truncated derivative of ClfA. The apparent molecular mass of the native ClfA protein of strain Newman thus appears to be $190 \mathrm{kDa}$.

Assuming that the largest immunoreactive protein is the native molecule, the ClfA proteins detected from some strains (e.g. strain V82) were smaller than expected. Nevertheless, in others there appeared to be a correlation between the size of the largest ClfA immunoreactive protein and the length of the $\operatorname{clf} A$ repeat region. Also, there did not appear to be an obvious correlation between the clumping titre and the amount of ClfA protein expressed, as judged qualitatively by examining the intensity of immunoreactive bands in Western blots (it should be noted that cells from the same culture were divided for the clumping assay, for the release of cell-wallassociated proteins and for the isolation of chromosomal DNA). However, strain Newman, which had the highest clumping titre, also expressed a high level of the ClfA protein, but strains C304/11 and Cowan which had the same clumping titre as Newman expressed significantly less protein. Perhaps variants have different affinity for 
fibrinogen or for the antibody or there may be strain to strain variation in release of ClfA or in its stability.

Much remains to be determined about the unique dipeptide repeat region of ClfA. It is still unknown whether this region of the protein is surface-exposed or is exclusively associated with the peptidoglycan found in the cell wall. Antibodies raised against the repeat region will be used to address this issue.

\section{ACKNOWLEDGEMENTS}

This work was funded by a Wellcome Trust project grant (no. 033403). We are grateful for the assistance of Gillian McNamara for some preliminary studies and to Denis Shields for analysing region $\mathrm{R}$.

\section{REFERENCES}

Ausubel, F. M., Brent, R., Kingston, R. E., Moore, D. D., Smith, J. A., Seidman, J. G. \& Struhl, K. (1987). Current Protocols in Molecular Biology. New York: John Wiley.

Bollet, C., Gevaudan, M. J., deLamballerie, X., Zandotti, C. \& deMicco, P. (1991). A simple method for the isolation of chromosomal DNA from Gram positive or acid fast bacteria. Nucleic Acids Res 19, 1955.

Cheung, A. \& Fischetti, V. A. (1989). Role of surface proteins in staphylococcal adherence to fibres in vitro. $J$ Clin Invest 83, 2041-2049.

Cottonaro, C. N., Roohk, H. V., Shimica, G. \& Sperling, D. R. (1981). Quantitation and characterisation of competitive protein binding to polymers. Trans Am Soc Artif Intern Organs 27, 391-395.

Duthie, E. S. \& Lorenz, L. L. (1952). Staphylocoagulase: mode of action and antigenicity. J Gen Microbiol 6, 95-107.

Fischetti, V. A., Jarymowycz, M., Jones, K. F. \& Scott, J. R. (1986). Streptococcal $M$ protein size mutants occur at high frequency within a single strain. $J$ Exp Med 164, 971-980.

Guss, B., Uhlen, M., Nilsson, B., Lindberg, M., Sjoquist, J. \& Sjodahl, J. (1984). Region X, the cell-wall-attachment part of staphylococcal protein A. Eur J Biochem 138, 413-420.

Hawiger, J. S., Timmons, S., Strong, D. D., Cottrell, B. A., Riley, M. \& Doolittle, R. F. (1982). Identification of a region of human fibrinogen interacting with staphylococcal clumping factor. Biochemistry 21, 1407-1413.

Hollingshead, S. K., Fischetti, V. A. \& Scott, J. R. (1987). Size variation in group A streptococcal $M$ protein is generated by homologous recombination between intragenic repeats. Mol \& Gen Genet 207, 196-203.

Humphreys, H., Keane, C. T., Hone, R., Pomeroy, H., Russel, R. J., Arbuthnott, J. P. \& Coleman, D. C. (1989). Enterotoxin production by Staphylococcus aureus isolates from cases of septicaemia and from healthy carriers. J Med Microbiol 28, 163-172.

Jones, T. O. \& Wiencke, A. A. (1986). Staphylococcal toxic shock syndrome. Vet Res 25, 435-436.

Jonsson, K., Signas, C., Muller, H.-P. \& Lindberg, M. (1992). Two different genes encode fibronectin binding proteins in Staphylococcus aureus. The complete nucleotide sequence and characterisation of the second gene. Eur J Biochem 356, 1-8.

Kristinsson, K. G. (1980). Adherence of Staphylococci to intravascular catheters. J Med Microbiol 28, 249-257.

Laemmli, U. K. (1970). Cleavage of structural proteins during the assembly of the head of bacteriophage T4. Nature 227, 680-685.
Maki, D. G. (1982). Infections associated with intravascular lines. In Current Topics in Infectious Diseases, vol. 3, pp. 309-363. Edited by J. S. Remington \& N. M. Swartz. New York: McGraw Hill.

McDevitt, D., Vaudaux, P. \& Foster, T. J. (1992). Genetic evidence that bound coagulase of Staphylococcus aureus is not the clumping factor. Infect Immun 60, 1514-1523.

McDevitt, D., Francois, P., Vaudaux, P. \& Foster, T. J. (1994). Molecular characterization of the clumping factor (fibrinogen receptor) of Staphylococcus aureus. Mol Microbiol 11, 237-248.

Olsson, A., Eliasson, M., Guss, B., Nilsson, B., Hellman, U., Lindberg, M. \& Uhlen, M. (1987). Structure and evolution of the repetitive gene encoding streptococcal protein G. Eur J Biochem 168, 319-324.

O'Reilly, M., Kreiswirth, B. \& Foster, T. J. (1990). Cryptic $\alpha$-toxin gene in toxic shock syndrome and septicaemia strains of Staphylococcus aureus. Mol Microbiol 4, 1947-1955.

Phonimdaeng, P., O'Reilly, M., Nowlan, P., Bramley, A. J. \& Foster, T. J. (1990). The coagulase of Stapbylococcus aureus. Sequence analysis and virulence of site specific coagulase deficient mutants. Mol Microbiol 4, 393-404.

Sambrook, J., Fritsch, E. F. \& Maniatis, T. (1989). Molecular Cloning: a Laboratory Manual, 2nd edn. Cold Spring Harbor, New York: Cold Spring Harbor Laboratory.

Shanson, D. C. (1990). Staphylococcal infections in hospitals. $\mathrm{Br} J$ Hosp Med 55, 312.

Signas, C., Raucci, G., Jonsson, K., Lindgren, P. E., Anantharamaiah, G. M., Hook, M. \& Lindberg, M. (1989). Nucleotide sequence of the gene for a fibronectin-binding protein from Stapbylococcus aureus: use of this peptide sequence in the synthesis of biologically active peptides. Proc Natl Acad Sci US A 86, 699-703.

Southern, E. M. (1975). Detection of specific sequences among DNA fragments separated by gel electrophoresis. $J$ Mol Biol 98, 503-517.

Stern, A., Brown, M., Nickel, P. \& Meyer, T. F. (1986). Opacity genes in Neisseria gonorrboeae: control of phase and antigenic variation. Cell 47, 61-67.

Uhlen, M., Guss, B., Nilsson, B., Gatenbeck, S., Philipson, L. \& Lindberg, M. (1984). Complete sequence of the staphylococcal gene encoding protein $A$, a gene evolved through multiple duplications. $J$ Biol Chem 259, 1695-1702.

Vaudaux, P., Pittet, D., Haeberli, A., Huggler, E., Kydegger, U. E., Lew, D. P. \& Waldvogel, F. A. (1989). Host factors selectively increase staphylococcal adherence on inserted catheters. A role for fibronectin and fibrinogen or fibrin. J Infect Dis 160, 865-875.

Vaudaux, P. E., Francois, P., Proctor, R. A., McDevitt, D., Foster, T. J., Albrecht, R. M., Lew, D. P., Wabers, H. \& Cooper, S. L. (1995). Use of adhesion-defective mutants of Staphylococcus aureus to define the role of specific plasma proteins in promoting bacterial adhesion to canine arterio-venous shunts. Infect Immun 63 (in press).

Vaudaux, P., Pittet, D., Haeberli, A., Lerch, P. G., Morgenthaler, J. J., Proctor, R. A., Waldvogel, F. A. \& Lew, D. P. (1993). Fibronectin is more active than fibrin or fibrinogen in promoting Staphylococcus aureus adherence to inserted intravascular catheters. $J$ Infect Dis 167, 633-641.

Yanisch-Perron, C., Vieira, J. \& Messing, J. (1985). Improved M13 phage cloning vectors and host strains : nucleotide sequences of the M13mp18 and pUC19 vectors. Gene 33, 103-119.

Received 9 September 1994; revised 28 November 1994; accepted 12 December 1994. 